\title{
THE EFFECT OF ONLINE LEARNING ON ACADEMIC INTEREST OF EVANGELICAL TEOLOGICAL SEMINARY OF INDONESIA - SURABAYA
}

\author{
Christian Melkianus Boka ${ }^{1)}$ Lilis Setyarini $^{2)}$ Willopo Koeswardoyo ${ }^{3)}$ \\ 1) Evangelical Theological Seminary of Indonesia - Surabaya \\ E-mail: christianmaikel@sttii-surabaya.ac.id \\ 2) Evangelical Theological Seminary of Indonesia - Surabaya \\ E-mail: lilissetyarini@sttii-surabaya.ac.id \\ 3) Evangelical Theological Seminary of Indonesia - Surabaya \\ E-mail: willopokoeswardoyo@sttii-surabaya.ac.id
}

\begin{abstract}
Interest in learning is an interest in a lesson and encourages individuals to learn and pursue the lesson, Interest in learning is an actualized desire or intention to be involved in certain learning activities while online learning is a learning process with the help of information and communication technology which is done online or virtual with not face to face. The online learning process carried out during the COVID-19 pandemic has had a major impact on education. This study aims to determine whether there is an effect of online learning on student interest in Evangelical Theological Seminary of Indonesia Surabaya. The research method used in this research is a quantitative research design with a survey method. Characteristics of respondents from 166 respondents who were the student population of Evangelical Theological Seminary of Indonesia - Surabaya studied consisted of age, education, and domicile. The contribution of the online learning variable in shaping the student's learning interest variable at Evangelical Theological Seminary of Indonesia - Surabaya is 55.6\%, the researcher argues that online learning is effective for continuous use and becomes a learning system that complements the traditional learning process.
\end{abstract}

Keywords: Online, learning, Education, Student, COVID-19 pandemic.

\section{INTRODUCTION}

Technological innovation in learning is a breeze fresh in the education system because it provides solutions to overcome problems in the traditional learning process. The real form of this innovation is the virtual learning process. According to Dabbagh Online learning is a learning system that is open and widely distributed and uses pedagogical tools (educational aids) made possible through the internet and network-based technology to facilitate the formation of learning processes and knowledge through meaningful action and 
interaction.[1] Virtual teaching and learning activities can be carried out by involving various components, namely teachers, students, objectives, materials, methods, media, evaluations, and learning resources to achieve the learning objectives to be achieved.[2] Kumar Basak stated that brave learning is a learning process that is supported by tools, digital electronic media, and wireless transmission to support the process.[3]

According to Fuadi, Some Benefits of Learning from Courage; 1) virtual teacher resources, which can overcome the limited number of lecturers, so that students do not need intensive support from lecturers, 2) the virtual school system, can open up opportunities for higher education without the need for space and time. The advantages of this bold learning system are that the student capacity is not limited and students can carry out the learning process anytime and anywhere, 3) cyber educational resources or dot com learning resources system is a supporter of bold learning, which can help access available electronic articles or journals. freely and for free on the internet.[4]

Previous research has mostly focused on the impact of online learning on learning effectiveness. Meanwhile, research related to the impact of online learning on the psychology of high school students of theology has not been done much. During the COVID-19 pandemic, online learning is becoming more and more common.

The Covid 19 pandemic forced changes in the learning process from traditional learning to online learning and forced every individual to adapt to a new environment and atmosphere. Christensen stated that these changes are no longer constant changes, he calls these changes innovations that actually bring about a decline (disruptive innovation), namely a period of radical change.[5]

This radical change will somehow turn into a new habit.[6] Online learning is understood as a learning process with the help of information and communication technology that is carried out online or virtual by not meeting face to face, using learning applications or social networks.

To Strive for a good learning process. Based on the above definition, it is known that online learning is a learning process. The online learning process through the help of interactive communication technology [7] and through the help of Web-based information technology. William stated Learning online connects and binds its users in this case Students and Lecturers so that all users can share their resources.[8]

Hasibuan argues that online 
learning is a virtual learning process with the help of applications such as Zoom, Google Meet, and so on as a means to support the learning process. Online activities include webinars, online classes, all activities are carried out using the internet and computer networks.[9]

Not a few experts also agree that online learning is a learning process that allows each individual to learn independently (asynchronously) and not face to face using the help of audio and video technology in devices.[10] Aviv added that the key to online learning using this system and the web is the ability of students to be part of the learning community and work together asynchronously to do learning assignments.

The implementation of this type of model is a participant group consisting of students, supervisors, experts, technicians, and lecturers) and is supported by a distributed computer system that includes information servers (www, ftp, libraries), related clients, and multi-way communication and devices. software such as electronic mail and conferencing systems.[11] Web-based online learning, (online instruction, elearning, or web-based learning), has three main functions, namely a supplementary function that is optional, a complementary function, and a substitution function in learning activities at school. inclass (classroom instruction).[12]

This online learning model is commonly applied to various forms of digital and online learning where students learn from instruction such as pre-recorded video lessons or game-based learning assignments that students complete on their own - which are not delivered in person or in real-time.[13]

Mahnegar in Winda Wijayanti, Nengah Maharta and Wayan Suana, stated that online learning is learning with the help of a system (Learning Management System) which is an application or software used to manage online learning, covering several aspects, namely material, placement, management, and assessment. This open source application is quite complete for an online class, starting from creating courses, class management, students, teaching materials and materials, to online exams that can be carried out with LMS and currently Moodle is a mandatory system in SPADA Indonesia used by all universities.

With the help of the System, students are able to follow the curriculum at their own pace without having to worry about scheduling issues. This may be the perfect 
choice for users who like to relax in each lesson plan in the curriculum, and prefer to find topics on their own. According to Pradiatiningtyas, Web-based online learning is a process receipt of material with the help of a system that presents information in the form of text, images, sound, etc. that are stored in an Internet Web server that is presented in the form of hypertext.[14] William W. Song, Anders Forsman, and Jia Yan stated that webbased online learning has several benefits, namely, the learning process can be carried out according to the interests of students. Very widely available learning materials on the web, various learning/teaching methods, and flexible infrastructure such as Peer to Peer or often called "end" to "end" technology.[15]

One of the conditions for its use in the learning process, educators and students must be connected to an adequate internet network. Indeed, the online learning process is not a new thing, not a few of the academic community are implementing it.

Jakarta Veterans National Development University, for example, has implemented a blended learning system that combines and integrates the conventional (class-based) education system with the digital-based Distance Education (PJJ) system (E-Learning).[16]
There are several important aspects that are quite important in the influence of online learning on students' interest in learning when participating in the online learning process, the first is the economic level of students. The results of research conducted by the SMERU Research Institute stated that the COVID-19 pandemic has the potential to increase the poverty rate in Indonesia.

The SMERU institute performs several projections of Indonesia's economic growth and in the worst-case scenario the poverty rate in 2020 increases by 4 percent from 2019 to around 12 percent.[17]

Senza Arsendy through his research to determine the implementation of the policy "Learn from" Rumah" in (INOVASI) for Indonesian school children. Based on the research they conducted from 4 provinces on May 2, 2020, there is a disparity in access to learning media, which is getting deeper between children from economically welloff and underprivileged families.[18] Online learning uses a device as a medium that occurs simultaneously, in real-time between students and teachers (real-time). In the process, online learning requires an atmosphere at home that supports learning, and must also have an adequate internet connection. 
Limited facilities and infrastructure also contribute to the difficulty of participating in online learning. As a result, they feel bored when learning takes place.[19] there are many distractions when studying at home, students feel less focused on learning without direct interaction with lecturers and other students, the material presented is difficult to understand, the lack of readiness of the lecturer in preparing the material.

Not to mention that the subject matter delivered is less efficient and difficult to understand, besides that problematic internet networks can add to the challenge of delivering the material well. L. Fuadi explained that effective communication in online learning must pay attention to two things, namely the way teaching materials are conveyed from teachers to students and the second is how to send a series of solutions that can improve students' knowledge and skills.[20]

Most of the material delivered during online learning was not well received by the students, they complained that the material presented was less efficient and difficult to understand. Not to mention if the internet network is problematic, it certainly adds to the challenge of delivering the material properly.[21] Online learning requires students to stay connected to their devices for a long period of time. The use of gadgets for a long time can have a negative impact on student health.[22] It seems that the solution to learning from home is actually create new problems. Reporting from CNN The policy of "learning from home" in response to the COVID-19 pandemic has a serious impact in the realm of education.

Distance learning (PJJ) risks hampering or even stopping the learning process for schools in remote areas due to limited internet access and costs that must be paid for each student. A study conducted by Hutomo Atman Maulana on the stress level of students who took part in the online learning process found that some students experienced stress levels above normal. The main factor that causes stress is the inability of students to adapt to the online learning process.[23]

The success of the process of learning and learning activities, apart from being influenced by the factor of the teacher, is also influenced by the factor of the student himself. Student behavior when following the learning process can indicate the student's interest in the learning or vice versa, he feels disinterested in the learning. This student interest is often known as interest. In this case, interest in learning is seen as a person's interest in the learning process. Interest is a feeling of liking the 
material and its need for the material, for example for the future life of the students concerned. Interest in learning is the main driver[24] or actualized intention to engage in certain learning activities. Interest, in this case, can be understood as liking, attention (tendency to something),[25] a sense of pleasure in facing the learning process [26] as a feeling of liking and being interested in learning activities, without anyone telling them to achievement, [27] Interest in learning as a feeling of pleasure that leads to a sense of liking for the learning process independently.

Tampubolon said that interest in learning is a combination of desire and willingness that can develop if there is motivation to carry out learning activities.[28] Tampubolon separates interest from motivation, interest is a person's liking or interest in a particular thing. While motivation is an impulse from within humans to carry out an activity. According to him, a person's liking or interest in a certain thing will generate encouragement or motivation to carry out an activity according to his interests.[29]

Djali argues that learning interest is basically an acceptance of something that has to do with oneself and something outside oneself to support the learning process.[30] Same to sees interest in learning as a constant tendency to pay attention and remember some learning activities.[31]

In addition to factors that influence from within, some experts see that interest in learning is influenced by several factors from outside of students. In a journal written by Abrantes, Seabra, and Lages on the effect of learning strategies on student interest and achievement, it is concluded that efficient instruction can affect students' interest in learning.

In other words, students' interest in learning is influenced by how the instructions from the teacher are.[32] Interest is not only seen as an impulse that comes from within but is also seen as an external drive. Overall Interest includes factors within and outside of a person. Interest that comes from within oneself to get what is important from these learning activities.

While the interest that comes from outside is an interest that comes from outside of the stimulation that someone gets from outside. Evangelical Theological Seminary of Indonesia - Surabaya students have been doing the online learning process since May 2020. Researchers suspect that there is a relationship between online learning that has been carried out on student interest in Evangelical Theological Seminary of Indonesia - Surabaya, so this study aims to determine whether there is an 
effect of online learning on student interest in learning at Evangelical Theological Seminary of Indonesia - Surabaya and to find out how much influence online learning has on student interest in learning, school Indonesian Evangelical Theological Seminary of Indonesia - Surabaya

\section{RESEARCH METHOD}

The research method used in this research is quantitative research design with survey method. It is called a survey because This study uses the direct population to be a representative sample to draw conclusions by using a questionnaire or questionnaire as a data collector. research aims to test the hypothesis that states the effect of the independent variable on the dependent variable.

The independent variable is online learning (hereinafter named variable $\mathrm{X}$ ), online learning is understood as a learning process with the help of information and communication technology that is carried out online or virtual by not meeting face to face, using learning applications, or social networks. To Strive for a good learning process. then the dependent variable is learning interest (variable Y). Interest in learning is an interest in an object which then encourages individuals to learn and pursue all things related to their interest in learning. Interest in learning obtained through the existence of a learning process is developed through the process of assessing an object which then results in an assessment. Certain assessments of objects cause a person's learning motivation.

Evangelical Theological Seminary of Indonesia - Surabaya students who are conducting the online learning process are scattered all over the world in various places, namely in Papua, NTT, East Java, Bali, Central Sulawesi, Surabaya, and surrounding areas. This research was carried out from October 2020 to April 2021. The design of this study was positivist (quantitative) using several points, namely design, population, research tools, data collection procedures, data analysis procedures, hypotheses, hypothesis testing, data reporting, and research sites.

Characteristics of respondents from 166 respondents who are the student population of Evangelical Theological Seminary of Indonesia - Surabaya who have studied, consisting of age, education, and domicile. A total of 102 students aged between 20 years - 30 years or $61.4 \%, 23$ students aged between 31 years - 40 years or $13.9 \%, 32$ students aged between 41 years - 50 years or $19.3 \%, 9$ students aged between $51-60$ years or $5.4 \%$. So the dominant respondents are students aged between 20 - 30 years or $61.4 \%$.

A total of 90 people are 
undergraduate students or $54.2 \%, 60$ masters students or $36.1 \%, 13$ people are doctoral students or $7.8 \%$, and as many as 3 students or $1.8 \%$ answered other education. It can be concluded that the majority of respondents came from undergraduate students, which was around $54.2 \%$.

A total of 148 students or $89.2 \%$ live in Java, 1 student or $0.6 \%$ live in Sumatra, 5 students or $3.0 \%$ live in Kalimantan, 4 students or $2.4 \%$ live in Sulawesi, as many as 4 students or $2.4 \%$ live in NTT, and 2 students or $1.2 \%$ live in Java. So it can be concluded that Evangelical Theological Seminary of Indonesia - Surabaya students are in several provinces in Indonesia and most respondents are in Java with a frequency of 148 students or $89.2 \%$.

\section{RESULTS AND DISCUSSION}

To answer the formulation of the problem, namely how much influence online learning has on student interest in Evangelical Theological Seminary of Indonesia - Surabaya. Researchers tested the instrument with validity and reliability tests, then the instrument was declared valid and reliable. Then the researchers processed the data by conducting normality and linearity tests, the authors used the Npar test for normality, the One-sample Kolmogorov-Smirnov test unstandardized
Residual with the Asymp value. Sig. (2tailed) 0.200. So according to the criteria that the normal sig value must be greater than 0.05 . So the data held by the researcher is normal.

With Variable Y, namely interest in online learning as the dependent variable and variable $X$ as the independent variable. The output description of the data can be seen that the significant value on Linearity is 0.000 . Because the significance is less than 0.05 , it can be concluded that there is a linear relationship between online learning variables and student interest in learning at Evangelical Theological Seminary of Indonesia - Surabaya.

From the value of Deviation from Linearity, it appears that Sig. $0.179>0.05$. It also shows that the two variables have a linear relationship. The results show that the distribution of online learning data and student interest in learning is normal and also linear.

Based on the results of the study, it is known that the value of Sig. is 0.000 . Because of the value of Sig. $0.000<0.05$, then according to the basis of decision making in the F test, it can be concluded that the hypothesis is accepted or in other words, online learning has an effect on student interest in learning at Evangelical Theological Seminary of Indonesia Surabaya. 
It is known that the significance value (Sig) of the online learning variable is 0.000. Because of the value of Sig. $0<$ probability 0.05 then it can be concluded that $\mathrm{H}$ or the hypothesis is accepted. This means that there is an effect of the variable $\mathrm{X}$ online learning on the variable Y Student Interest in Evangelical Theological Seminary of Indonesia - Surabaya.

Based on the research, it was found that the R-value was 0.746 and was positive. Based on the guidelines for interpreting the correlation coefficient as written in the research methodology in the previous chapter, the relationship between the Online Learning variable and the Student Learning Interest variable at Evangelical Theological Seminary of Indonesia - Surabaya is included in the category of a strong relationship.

It is known that the value of $\mathrm{R} 2$ (coefficient of determination) in this study was obtained at 0.556 or $55.6 \%$. This means that the contribution of the online learning variable informing the variable of student interest in Evangelical Theological Seminary of Indonesia - Surabaya $55.6 \%$. The remaining $44.4 \%$ is explained by other factors outside this research model.

The constant is 11.937 , meaning that if learning online the value is 0 , then the student's interest in learning is 0.681 . The regression coefficient of the online learning variable is 0.681 ; This means that if learning online has increased by one unit, then student interest in learning will increase by 0.681 units. if every improvement in online learning increases once, then the interest in learning of STTII Surabaya students will increase by 0.681 times.

\section{CONCLUSION}

So based on the results of the research above, it can be concluded that the hypothesis in this study, that there is an effect of online learning on student interest in learning at Evangelical Theological Seminary of Indonesia - Surabaya and the magnitude of the influence tends to be strong, is proven.

After going through an in-depth study, both through literature, surveys, and data processing, it was obtained that the contribution of online learning $(\mathrm{X})$ to the learning interest of Evangelical Theological Seminary of Indonesia Surabaya students (Y) was 55.6\%, which means strong. So online learning has a strong effect on student interest in Evangelical Theological Seminary of Indonesia - Surabaya. According to Researchers Learning online effective for use in the future and become a learning system that complements the traditional learning process. Online learning can be used as a solution for students who 
are hindered from learning by time and place.

Online learning provides an opportunity for students to upgrade their technology skills and helps students adapt easily to the radical changes that occur.

\section{REFERENCES}

[1] Dabbagh, N. and Ritland. B. B, Online Learning, Concepts, Strategies And Application, (Ohio: Pearson), 26

[2] Wina Sanjaya, Learning Planning and Design, (Jakarta; Kencana, 2010), 26

[3] Sujit Kumar Basak, Marguerite Wotto, and Paul Bélanger, E-Learning, $M$ Learning and D-Learning: Conceptual Definition and Comparative Analysis, ELearning and Digital Media, 15.4 (2018), 191-216

[4]. L. Fuadi, T. M., Musriandi. R., \& Suryani, Covid-19: Application of Online Learning in Higher Education (Journal of Education Dedication, 4.2 2020), 93-200.

[5] Ridwan Sanjaya, 21 Reflections on Online Learning in an Emergency Period (Semarang: SCU

Knowledge Media, 2020), 1-3

[5] Ridwan Sanjaya, 21 Reflections on Online Learning in an Emergency Period (Semarang: SCU Knowledge Media, 2020), 1-3

[7] Isniatun munawaroh. Virtual Learning in distance learning. Journal of scientific learning magazine number 2 Volume 1 October 2005, KTP FIP UNY, 172

[8] V. Williams, British Journal of Learning Disabilities, (Wiley Online Library, 1999), 15

[9] Hasibuan, MS \& Simarmata, Janner \& Sudirman, Acai. E-Learning: Implementation, Strategy and Innovation. ( Medan: Our Writing Foundation, 2019), 19 [10] Elizabeth Murphy, María A. Rodríguez-Manzanares, and Michael Barbour, 'Asynchronous and Synchronous Online Teaching: Perspectives of Canadian High School Distance Education Teachers', (British Journal of Educational Technology, 42.4 2011), 83-91

[11] Reuven Aviv, 'Educational Performance of ALN via Content Analysis', Journal of Asynchronous Learning Network, 4.2 (2000), 53-72

[12] Pradiatiningtyas, Diah, and Suparwanto, 'E-Learning as a Web-Based Learning Media at Smk N 4 Purworejo', Indonesian Journal on Networking and Security, 7.2 (2017), 1-8

[13] Indira Dhull MS. Sakshi, 'Online Learning', Quality in Primary Care, 12.1 (2004), 87-89

[14] Diah Pradiatiningtyas and Suparwanto, E-Learning as a Web-Based Learning Media at Smk N 4 Purworejo 
Journal Didaskalia

E-ISSN: 2621-8054

P-ISSN: 2622-1667

(Indonesian Journal on Networking and

Security - Volume 7 No 2 - 2017), 1-8

[15] William W. Song, Anders Forsman, and Jia Yan, 'An E-Curriculum Based Systematic Resource Integration Approach to Web-Based Education', International Journal of Information and Education Technology, 5.7 (2015), 495-501

[16] Ramzi Zainal Abidin, Guidelines for the Implementation of Distance Education. University Jakarta Veterans National Development. 2020, iv

[17] Asep Suryahadi, Ridho Al Izzati, Daniel Suryadarma. Impact of the COVID19 Pandemic on Poverty: Estimates for Indonesia. April 2020.

[18] The Conversation. Research on the impact of covid 19. Portrait of the online access gap learning from home.

[19] Oktafia Ika Handarini and Siti Sri Wulandari, Online Learning as a Study From Home (SFH) Effort During the Covid 19 Pandemic. Journal of Office Administration Education (JPAP) Volume 8, Number 3, 2020, 491-502

[20] 4L. Fuadi, T. M., Musriandi. R., \& Suryani, Covid-19: Application of Online Learning in Higher Education (Journal of Education Dedication, 4.2 2020), 193-200.

[21] Redjeki Agoestyowati, Positive and negative impacts of online learning during the covid-19 pandemic, (Journal of AKSARA PUBLIC Journal Volume 4
Number 3 August 2020 Edition (117-123), 119-120.

[22] Dr. Sunrise Princess. Quoted from Click doctor. The negative impact of smartphone use on health.

[23] Hutomo Atman Maulana, Rosada Dwi Iswari, Analysis of Student Stress Levels on online learning in the Business Statistics course in vocational education, (Education Scientific Journal, Vol. XIV, No. 1, September 2020), 17-29

[24] Andi Achru P, 'Development of Interest in Learning in Learning', III.36 (2019), 205-15.

[25] WJS. Poerwodarminto, General Indonesian Dictionary, (Jakart: Balai Pustaka, 1984), 134.

[26] Muhammad Fathurrohman, Sulistyorini, Learning and Learning, (Yogyakarta: Teras, 2012), 173.

[27] Nashar, The Role of Motivation and Early Ability in Learning Activities, (Jakarta: Delia Press. 2014), 42

[28] Tampubolon, Developing Interests and Reading Habits. (Bandung: Angkasa, 1991), 41

[29] Tampubolon, Developing Interests and Reading Habits. (Bandung: Angkasa, 1991), 41

[30] Djaali. Educational Psychology. (Jakarta: Bumi Aksara,2008), 121

[31] Slameto. Learning and the factors that 
Journal Didaskalia

E-ISSN: 2621-8054

P-ISSN: 2622-1667

influence it, (Jakarta: Rineka Cipta, 2003), 57

[32] Abrantes, José Luís, et al.

"Pedagogical Affect, Student Interest, and

Learning Performance." Journal of

Business Research, vol. 60, no. 9, 2007, 60-

64 